\title{
Governing authorities in the same boat and a tale of two schedules: Marius Nel v Hessequa Local Municipality (2015)
}

\section{Anél du Plessis \\ Faculty of Law \\ North-West University \\ South Africa}

Email: anel.duplessis@nwu.ac.za

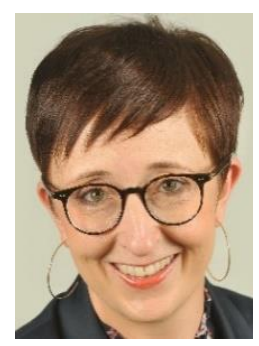

\section{Oliver Fuo}

Faculty of Law

North-West University

South Africa

Email: oliver.fuo@nwu.ac.za

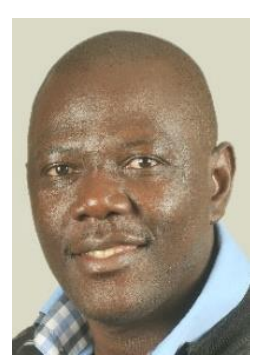

\begin{abstract}
This article responds to the tension inherent in the Constitution of the Republic of South Africa 1996 which lists 'the environment' proper as a function of national and provincial government. The authors discuss one of the arguments raised in the recently decided case of Marius Nel and Others v Hessequa Local Municipality and Others (2015) with particular emphasis on what the court's reasoning adds to the growing body of jurisprudence on local government's authority to govern environmental matters and the need for cooperative environmental governance in the South African context. The article features an overview of the relevant facts and findings in the Hessequa case, followed by a discussion of the implications of the court's judgment.
\end{abstract}




\section{Introduction}

The Constitution of the Republic of South Africa 1996 ('the Constitution') is often acclaimed for its Bill of Rights, its values and attendant groundbreaking judgments on matters such as the right to life, ${ }^{1}$ the right to access to adequate housing, ${ }^{2}$ the authority of the Public Protector, ${ }^{3}$ the prohibition of corporal punishment in schools ${ }^{4}$ and the extension of social assistance grants to non-South Africans with permanent residence status. ${ }^{5}$ Less celebrated are the inroads the Constitution has made in changing the allocation and division of power or governing authority between the various organs of state in democratic South Africa (Schedules 4 and 5 of the Constitution; Olivier 2015; Fuo 2015). The Constitution (Section 40(1)) has had a remarkable impact on the division of legislative and executive authority between national, provincial and local government spheres and, in so doing, on the way in which authorities can and should govern. Since 1996, municipalities have unprecedented governing powers and have become a sphere of the South African government with a level of responsibility that has historically been unknown (Du Plessis 2010, pp. 265-269; Fuo 2014, pp. 109-117). There has been a total change in the scope and depth of the legislative and executive authority, as well as the status of local government (Sections 151(2) and (3) read with Section 156 of the Constitution; City of Cape Town $v$ Robertson paras. 55-60; Fuo 2015, pp. 20-26; Christmas and De Visser 2009). These changes have in recent years precipitated a number of court cases challenging the governing authority of municipalities, such as City of Johannesburg v Blue Moonlight Properties and Le Sueur v eThekwini Municipality.

The constitutional transformation of local government has however resulted in a number of uncertainties. While the Constitution a) stipulates the developmental duty and a number of other objects of municipalities (Sections 152 and 153); b) dictates in general how the three spheres of government should coordinate their financial and other business (Sections 154(1), 41(1)(h) and 215); and c) sets out in Schedules 4 and 5 how some areas of governance and competences are divided between the national, provincial and local spheres, it is silent on many aspects. There is very little detail on the execution of the executive authority of the national, provincial and local authorities. Furthermore, other than offering

\footnotetext{
${ }^{1}$ In $S v$ Makwanyane and Another (1995), the Constitutional Court declared the death penalty unconstitutional inter alia because it violated the rights to life and dignity.

${ }^{2}$ In Government of the Republic of South Africa and Others v Grootboom and Others (2000), the Court declared that the housing policy of the Cape Metro failed to meet the constitutional requirements of reasonableness because it did not cater for the needs of those in desperate conditions. It ordered the national government to devise and implement a coherent and coordinated housing programme to give effect to the right to access to housing guaranteed in Section 26(1) of the Constitution.

${ }^{3}$ Recently, in Economic Freedom Fighters $v$ Speaker of the National Assembly and Others and Democratic Alliance v Speaker of the National Assembly and Others [2016], the Constitutional Court ruled that the findings and remedial actions of the Public Protector are binding and can be reviewed and set aside only by a court of law.

${ }^{4}$ See Christian Education South Africa v Minister of Education (2000).

${ }^{5}$ See Khosa and Others $v$ Minister of Social Development and Others, Mahlaule and Another v Minister of Social Development (2004).
} 
principles for cooperative government in Chapter 3 and demanding good intergovernmental relations, ${ }^{6}$ there are barely any specific guidelines on how organs of state should co-govern.

The absence of any specific guidelines on how to co-govern is further complicated by the framing of the environmental duties of the three spheres of government in the 1996 Constitution. The Constitution (Sections 7(2) and 24, read jointly) demands of all three spheres of government to respect, protect, promote and fulfil the right of everyone to an environment that is not harmful to human health or wellbeing, yet it lists the "environment" as a "functional area of concurrent national and provincial legislative competence" (Schedule 4A). This seems to suggest that only national and provincial deliberative bodies (Parliament and the National Council of Provinces) can pass legislation to regulate environmental matters. This allocation of authority in respect of environmental matters is featured in cases such as Le Sueur v eThekwini Municipality, Maccsand (Pty) Ltd v City of Cape Town, Lagoon Bay Lifestyle Estate (Pty) Ltd v Minister of Local Government, Environmental Affairs and Development Planning of the Western Cape and, most recently, in the cases of Marius Nel v Hessequa Local Municipality (hereafter 'the Hessequa case') and Abbott v Overstrand Municipality.

This article discusses one of the arguments raised in the Hessequa case, with particular emphasis on how the court's reasoning adds to the growing body of jurisprudence on local government's authority to govern environmental matters and the need for cooperative environmental governance ${ }^{7}$ in South Africa. The discussion commences with an overview of the relevant facts and findings in the Hessequa case and then offers some views on the implications of the court's judgment.

\section{Marius Nel v Hessequa Local Municipality - facts and findings}

Between 2012 and 2013 the Hessequa Local Municipality and the Swellendam Municipality adopted by-laws relating to the management and use of rivers within their jurisdictional areas - the Breede, Goukou, Gouritz and Duiwenhoks Rivers (Hessequa case, para. 5). Sections of the by-laws sought to regulate various boating activities and required, inter alia, that boats using the rivers should be licensed by the municipalities.

The by-laws make provision for boat licensing fees and the cancellation of licences, and the fixing of tariffs, fees and levies by the municipalities in respect of the registration and licensing of boats. The bylaws equally prohibit some behaviour relating to the use of boats, fishing and other activities on the river, including operating a boat in a reckless manner, while under the influence of drugs or alcohol, when overloaded, or when the boat is leaking pollutants. The by-laws make the contravention of these

\footnotetext{
${ }^{6}$ See Section 41 of the Constitution.

${ }^{7}$ Environmental governance in this context denotes the regulatory functions of government in relation to environmental matters and implies the attempt to govern behaviour by setting and enforcing environmental standards, rules and principles through execution of legislative, executive and administrative functions. For details, see Du Plessis (2010, pp. 269-271).
} 
requirements an offence (para. 5). To ensure compliance with their provisions, the by-laws prescribe the powers of authorised officers inter alia to investigate, test and remove boats from the rivers. Officers are authorised to board vessels, to request information including the names and addresses of persons on board, and to order an unlicensed boat user to remove the boat from the river (para. 7). In a case of noncompliance with the latter order, the municipality has the power to remove such a boat, and if it is not claimed within 90 days of removal the municipality may seize it (para. 7).

The applicants, owners of holiday homes in the Breede River, approached the High Court to declare the adopted by-laws unconstitutional, in conflict with national legislation and therefore invalid, first on the ground that municipalities do not have powers to legislate on the use of rivers (paras. 2-3 and 9). Secondly, the applicants argued that the powers given to the appointed officers (tasked with ensuring compliance) to search vessels were draconian and violated the right to privacy (para. 17). Thirdly, they argued that the requirement for a boat licence was inconsistent with the provisions of the National Water Act (no. 36 of 1998) ('the NWA'), which makes it possible for a person who has lawful access to a water resource to use it for recreational purposes (paras 24 and 25). Fourthly, they argued that the powers of authorised officers appointed in terms of the by-laws were wider than the powers vested in fisheries control officers (appointed by the Minister) under Section 51 of the Marine Living Resources Act (no. 19 of 1998) ('the MLRA'). On this basis, the applicants argued that both the power of the municipalities to authorise persons to perform the functions of authorised officers under the by-laws and the specific powers conferred on the authorised officers were inconsistent with the MLRA and therefore invalid (para. 30). Lastly, they argued that there was a conflict between some provisions of the by-laws and the Criminal Procedure Act (no. 51 of 1977) ('the CPA') in relation inter alia to the powers of police officers to enter and search premises for the purpose of obtaining evidence (para. 33).

On the first issue raised by the applicants, the Court held that it is entirely permissible for a municipality to make by-laws requiring inter alia that people wishing to use boats on rivers and/or to fish in rivers in its area of jurisdiction be licensed, and to authorise officers to enforce such by-laws (paras. 13 and 16). The Court reasoned that a reading of Section 156 of the Constitution, ${ }^{8}$ together with Schedules 4B and $5 \mathrm{~B}$, gives municipalities powers to regulate the use and management of rivers within their jurisdictional area. The Court indicated that the relevant local government matters listed in Schedule 5B of the Constitution in the context of this case include 'local amenities', 'municipal recreation', and 'public spaces'. The Court held that rivers, which constitute the subject matter of the by-laws, fall within the

\footnotetext{
${ }^{8}$ Section 156 of the Constitution provides that: "(1) A municipality has executive authority in respect of, and has the right to administer - (a) local government matters listed in Part B of Schedule 4 and Part B of Schedule 5; and (b) any other matter assigned to it by national or provincial legislation. (2) A municipality may make and administer by-laws for the effective administration of the matters which it has the right to administer. (3) Subject to Section 151(4) a by-law that conflicts with national or provincial legislation is invalid. If there is a conflict between a by-law and national or provincial legislation that is inoperative... the by-law must be regarded as valid for as long as that legislation is inoperative... (5) A municipality has the right to exercise any power concerning a matter reasonably necessary for, or incidental to, the effective performance of its functions."
} 
scope of public amenities, public places and places of recreation. The Court noted that navigable rivers which flow within the jurisdictional areas of both Hessequa Local Municipality and Swellendam Municipality provide many recreational opportunities for members of the public, which if not appropriately regulated might result in disorderly conduct in public spaces which could disturb the peaceful enjoyment of residents and visitors to the municipal areas (para. 11). Furthermore, the Court observed that the powers of both municipalities to pass the by-law was consistent with their obligation flowing from a joint reading of Sections 24 and 152(1)(d) of the Constitution to promote a safe and healthy environment as well as to uphold the rights of everyone to an environment not harmful to their health and well-being. The Court further observed that the powers to make laws that regulate the management and use of navigable rivers within municipal jurisdictions is reinforced by the fact that all organs of state are equally bound to give effect to the principles of the National Environmental Management Act (no. 107 of 1998) ('NEMA') (para. 13).

The Court further observed that the fact that national and provincial spheres of government also have functional competence over public rivers in the jurisdiction of municipalities does not exclude the competence of such municipalities (para. 14). Drawing from earlier jurisprudence regarding the overlap of powers and functions across the three spheres of government, the Court reiterated that these spheres have to co-exist and regulate the use of public navigable rivers from a sphere-specific perspective where the context so requires (paras. 15-16). The Court restated the established view that, where the exercise of power by different spheres of government overlaps, no sphere should be seen as intruding into the functional area of another. Each sphere would therefore be exercising power within its competence as guided by the principles of cooperative government (para. 16).

In relation to the second argument, the Court held that the powers of appointed officers to conduct random inspections of boats in public places within the jurisdiction of the municipalities in order to ensure orderly conduct for recreational purposes did not violate the right to privacy (paras. 17-23). The Court held that no infringement of the right to privacy occurred through the performance of periodic regulatory inspections of boats and equipment on public rivers, or the calling of those in control of or on such boats to furnish their names and addresses, or to provide information concerning the boats, as authorised by the by-laws (para. 23). The Court compared this situation to that of police officers randomly pulling drivers aside to check their licences and to gather information for that purpose (para. 23). Drawing from the jurisprudence of the Constitutional Court, the Court observed that the right to privacy must be limited to comply with reasonable regulation and to tolerate administrative inspections that are an inseparable part of a regime of regulation (paras 17-23). The Court observed that the powers of appointed officers are part of an effective regime of regulation of boats on the rivers, which requires that the expectation of privacy by boat users should be abated (para. 21). The Court observed that although the by-law gives appointed officers powers to conduct routine inspections and in some instances give instructions for boats to be taken off the river, it did not make any provision for seizure. 
In terms of the by-law, unclaimed boats could be seized by the municipalities only after obtaining a court order. The Court observed that this approach was different from that adopted in general search and seizure provisions (para. 22). The Court noted that the by-laws provide for routine inspections in a public river only in order to ensure that both the boats, and those who control them, are in a suitable condition in the interests of the public and their safety (para. 22). The Court found that the measures contemplated in the by-law could be justified on the basis of the general limitation clause contained in Section 36 of the Constitution. ${ }^{9}$ The Court concluded that the measures contained in the by-law were reasonable and justifiable in an open and democratic society based on freedom and equality (para. 23).

In relation to the third argument raised by the applicants, the Court ruled that any entitlement to the use of water under the NWA is subject to any other law, by-law, ordinance, regulation or limitation imposed by the Act. The Court noted that the NWA expressly recognises that through cooperative governance a responsible authority may promote arrangements with organs of state to combine their respective licence requirements into a single requirement (para. 25, Section 22(4) of the NWA). The Court held that the fact that the municipalities imposed licence requirements for boating in public rivers through by-laws did not conflict with the NWA. The licence requirements were imposed from a municipal perspective as permitted by the legislation and their overlapping constitutional powers and functions (para. 26).

The Court rejected the fourth argument raised by the applicants on the basis of the existing constitutional authority of municipalities (para. 31). It held that it was within the powers of the respondents to make by-laws regulating boating on the public rivers in their areas of jurisdiction and to appoint and empower officers to ensure compliance with the provisions of the by-laws. The Court held that the fact that the MLRA also applies to fishing on the rivers and the fact that the National Minister creates posts for fisheries control officers with law enforcement powers does not create a conflict with the by-laws. While the MLRA was confined to the regulation of fishing, the by-laws regulated non-fishing boating activities. The Court noted that these are two different regimes operating side by side (para. 31). The Court held that the powers of authorised officers under the MLRA were wider than those in the bylaws. This was because unlike authorised officers under the by-laws, those of the MLRA had powers for search, seizure and arrest (para. 32).

Finally, in relation to the potential clash between the CPA and the by-laws, the Court indicated that the former was applicable to 'premises' and not to boats. The Court held that there was no conflict between

\footnotetext{
${ }^{9}$ Section 36 of the Constitution provides that: "(1) The rights in the Bill of Rights may be limited only in terms of law of general application to the extent that the limitation is reasonable and justifiable in an open and democratic society based on human dignity, equality and freedom, taking into account all relevant factors including - (a) the nature of the right; (b) the importance of the purpose of the limitation; (c) the nature and extent of the limitation; (d) the relationship between the limitation and its purpose; and (e) less restrictive means to achieve the purpose. (2) Except as provided in subsection (1) or in any other provision of the Constitution, no law may limit any right entrenched in the Bill of Rights."
} 
the by-laws and the CPA (para. 34). The Court held that it was permissible for the by-laws to confer enforcement powers on persons tasked with ensuring compliance, irrespective of the fact that similar powers are generally conferred on the police or peace officers by the CPA (para. 35). The conferral of similar powers did not invalidate the provisions of the by-laws. The Court dismissed the application with costs (para. 36).

\section{Implications of Hessequa case for local government law in South Africa}

As evident from the Hessequa case, one of the most pressing challenges facing developmental local government is its poorly defined functions and powers. The limits to powers have been a source of great concern and confusion for municipalities since the creation of the new local government dispensation. The lack of clarity has often resulted in the duplication of duties, confusion, inefficiencies and arguably even deterioration in the delivery of services to communities. In worst case scenarios it has led to intense animosity between provincial governments and municipalities, which have sometimes reached an impasse in respect of which sphere should perform a particular function (Christmas and De Visser 2009, pp. 110-11). In other instances, such as in the case of Hessequa, it creates a potential way to avoid legal compliance for the affected individuals.

National and provincial environmental legislation and the Bill of Rights in the Constitution recognise the part to be played by the local sphere in managing and controlling the environment - which, as in the case of Le Sueur, renders it "inconceivable that municipalities were to be excluded from legislating in respect of environmental matters, notwithstanding the listing of 'environment' in Part A of Schedule 4" (Humby 2014, p. 1671). Still, the argument is often raised that local government may take on environmental duties and assume environmental authority only once such duties or authority have been assigned to them. As the Hessequa case illustrates, this argument flies in the face of the constitutional demand for 'developmental local government', the principle of subsidiarity entrenched in Section 156(4) of the Constitution, and the fulfilment of the duties arising from Section 24 of the Constitution. Section 156(5) of the Constitution allows a municipality to exercise any power reasonably necessary for or incidental to the effective performance of its functions. These functions are not described and cannot reasonably be read to refer only to original 'powers' listed in Schedules $4 \mathrm{~B}$ and $5 \mathrm{~B}$. A municipality that has the necessary resources can legislate and enforce by-laws on matters listed in Schedule $4 \mathrm{~A}$ and $5 \mathrm{~A}$ of the Constitution provided that such action seeks to further the objectives of Section 24 of the Constitution and is not in conflict with measures adopted by the national and provincial spheres (Fuo 2015, p. 32). Given the difficulty of containing environmental concerns to one functional or geographic area of jurisdiction, collaboration and cooperation between the different spheres of government is essential if the objectives of Section 24 of the Constitution are to be realised (Olivier 2015, p. 365). Even where the powers and functions of the various spheres appear to be distinct, they should not be exercised in isolation of another sphere or in competition with another sphere (Steytler 
and De Visser 2014, Chapter 16, p. 3; Olivier 2015, pp. 365-369). There is a positive constitutional duty on all spheres of government to cooperate in securing the objectives of the Constitution.

The facts in the Hessequa case also point to the potential role of municipalities in enforcing national, provincial and local environmental standards in South Africa. Snijman and Petterson (2015) make a convincing case for local government enforcement as part of the broader environmental law enforcement effort in South Africa. In explaining that local government has a primary and supportive role in environmental law compliance in South Africa, they state inter alia that:

As a result of the somewhat misleading division of regulatory functions and powers in Schedules 4 and 5 of the Constitution, the general perception that local government is only in a position to deal with minor environmental transgressions is not correct. It is also not correct to think that a municipality contributes to the overall environmental enforcement effort merely by enforcing its by-laws... a municipality's contribution to environmental enforcement must be seen through the lens of cooperative government and the collective environmental responsibilities and duties of all the organs of state in the national, provincial and local spheres. The wall-to-wall local government system suggests that, together, municipalities are confronted with issues such as the destruction of wetlands, illegal mining and organized environmental crime. This said, the role of local government is not to create an enforcement system that aims to supplant specific enforcement structures such as the South African Police Services (SAPS) or provincial or national departments with specific environmental mandates. Local government is ideally positioned to augment and support the enforcement efforts of these institutions in the spirit of cooperative government... municipalities being closest to the people they govern, usually have the advantage of local knowledge over their provincial or national counterparts, who work in small teams that must cover large geographical areas incorporating a number of municipalities ... municipal officials may possess more precise and up-to-date information than provincial and national authorities - information that is often crucial in investigations (Snijman and Petterson 2015, pp. 292-293).

While the Court in the Hessequa case emphasised cooperative government in the environmental governance context, it unfortunately did not fully develop its reasoning in terms of what cooperative government means for a) the actual execution of environmental governance (e.g. compliance and enforcement and authorisations) within and across the three spheres of government; or b) how multiple organs of state are to deal with overlap in relevant areas of governance. ${ }^{10}$ The court was silent on the interconnectedness of environmental issues such as water use, water pollution, ecosystem services, environmental health, eco-tourism and the conservation of biodiversity.

From the discussion above, it appears that the local government 'environmental' functions listed in Schedules 4B and 5B of the Constitution do not enable municipalities to make the maximum social, economic and environmental impact envisaged by the Constitution or local government and environmental legislation. It is disturbing that 20 years of application of the Constitution has not yet resolved the mismatch between the notion of developmental local government and the power of

\footnotetext{
${ }^{10}$ It is noteworthy that intergovernmental coordination and integration are widely perceived as complexities in environmental law that must be addressed. This challenge is not unique to South Africa. See for example Godden and Peel (2010, pp. 277-279).
} 
municipalities to make and enforce certain local laws. The present authors fully agree with Christmas and De Visser (2009, p. 108), who hold that "the impact of the collective efforts of national, provincial and local government in fulfilling their constitutional obligations to citizens must be tangibly seen and felt at the local level".

When we ask the question which powers and functions are best vested at local government level, a number of general indicators previously developed by the Community Law Centre ${ }^{11}$ at South Africa's University of the Western Cape are quite useful. The Centre's research suggests that attention should be paid to: a) the degree to which economies of scale may be obtained at a higher level; b) whether the function has spill-over effects; c) whether there is the capacity to execute the function; d) whether intersectoral coordination is required; e) whether grass-roots community participation is required; and f) whether the function adds to policy control over the built environment (Community Law Centre 2007, pp. 18-19). This paper suggests that we should ask the same questions in relation to the powers of municipalities over environmental matters and the enforcement of environmental law - regardless of whether we do so in relation to by-laws or the laws of national and provincial authorities. It has been stated by Snijman and Petterson (2015, p. 295) that enforcement is a tool:

To improve environmental compliance and a means by which government protects the constitutional right of the people in South Africa to an environment that is not detrimental to health or well-being. Some minor instances of non-compliance may warrant nothing more than an informal response on the part of a municipality or another authority such as a warning or a negotiated compliance outcome. Other crimes may require the mixed use of various compliance and enforcement mechanisms, that may need different authorities to act swiftly and in a very firm way.

The vehicle of cooperative governance may be appropriate for the South African democratic context, but "having three spheres of government operating each with a degree of autonomy makes for complex relationships, which also impact on the effectiveness and efficiency of government" (Christmas and De Visser 2009, p. 109). It is also important to remember that the fact that a power or competence is or is not an 'original' local government function has no bearing on the oversight powers of national and/or provincial government. A municipality's authority over its 'original' functions is anything but unfettered. The national and provincial governments oversee the municipal performance of 'original' functions through the legislative framework within which municipalities must operate. All local government service delivery and efforts to protect the environment come together in the municipal arena. At the same time, municipal responsibility centres on controlling the immediate environment that is, the spatial and physical aspects of service delivery and government regulation. We should ask ourselves whether the fact that a function is not listed in Schedule 4B or 5B means that local government has no responsibility in the matter - in spite of the duties that arise for municipalities from their

\footnotetext{
${ }^{11}$ The Community Law Centre is a research centre at the University of Western Cape, which also takes part in social activism.
} 
responsibility for people's rights, their development duties, and their need to respect the system of cooperative government. Drawing on the jurisprudence of South African courts, Fuo (2015, p. 32) explains that:

... there is nothing which prevents municipalities that have the resources to self-fund environmental projects that typically fall within the legislative area of competence of national and provincial government - as defined by Schedules $4 A$ and $5 A$ - in so far as such projects seek to further the objectives of Section 24 of the Constitution and are not in conflict with national and provincial programmes. It now appears that, when exercising its original and assigned powers and functions, a municipality can adopt by-laws to protect against improper invasion any environmental matters listed in Schedules $4 \mathrm{~A}$ and $5 \mathrm{~A}$ of the Constitution in so far as this relates to its functions and to the extent that the by-law does not conflict with a provincial and national legislation. This is connected to the incidental administrative powers conferred on municipalities by Section 156(5) of the Constitution. A close reading of the Constitutional Court's jurisprudence... suggests that a municipality can do anything to foster constitutional objectives provided such action is not illegal.

It follows from the above that Schedules $4 \mathrm{~B}$ and $5 \mathrm{~B}$ of the Constitution are basic areas where all municipalities across the country can and should exercise legislative, executive and administrative authority in relation to the environment. Even where a function does not expressly fall within Schedules 4B and 5B, a purposeful interpretation of local government's constitutional environmental powers and functions gives municipalities the space to promote the sustainability agenda. The reasoning of the Court in the Hessequa case takes this direction: a reading inter alia of Section 156 of the Constitution, together with Schedules $4 \mathrm{~B}$ and $5 \mathrm{~B}$, empowers municipalities to regulate the use and management of rivers within their jurisdictional area. It would defy logic for municipalities to have legislative and executive competence over functional areas related to rivers - such as pollution control; pontoons, ferries, jetties and piers; beaches and amusement facilities; public nuisances; local amenities; public places; and municipal health services - without the ancillary power to regulate aspects of the use and management of rivers within their jurisdictions.

It should be noted that, just as in Le Sueur, it was not a national or provincial sphere of government that challenged the reach of local government's environmental powers and functions in the Hessequa case. The challenge - as in several similar cases - came from community members who attempted to exploit gaps in the manner in which local government's environmental powers and functions have been defined. This suggests that while national and provincial government may readily welcome initiatives from municipalities to contribute towards meeting the environmental objectives of the Constitution, members of the community often attempt to evade the far-reaching governing powers of municipalities, as they are perceived to impose additional responsibilities on them or to limit their liberties. However, attempts to evade the reach of local government's powers on the basis of its often ill-defined functions have repeatedly been struck down by courts - and the Hessequa case is no exception. 


\section{Declaration of conflicting interest}

The authors declared no potential conflicts of interest with respect to the research, authorship, and/or publication of this article.

\section{Funding}

The authors received no financial support for the research, authorship, and/or publication of this article.

\section{References}

Abbott v Overstrand Municipality. [2016] ZASCA 68 (delivered by the Supreme Court of Appeal on 20 May 2016).

Christian Education South Africa v Minister of Education. (2000) (10) BCLR 1051 (CC) (verdict delivered by the Constitutional Court on 18 August 2000).

Christmas, A. and De Visser, J. (2009) Bridging the gap between theory and practice: Reviewing the powers and functions of local government in South Africa. Commonwealth Journal of Local Governance, 2, 107-19. https://doi.org/10.5130/cjlg.v0i2.999

City of Cape Town v Robertson. (2005) (2) SA 323 (CC) (verdict delivered by the Constitutional Court on 29 November 2004).

City of Johannesburg Metropolitan Municipality v Blue Moonlight Properties 38 (Pty) Ltd and Another. (2012) (2) BCLR 150 (CC) (verdict delivered by the Constitutional Court on 1 December 2011).

Community Law Centre. (2007) Paper I: Development local government: Determining appropriate functions and powers. Cape Town: Community Law Centre, University of the Western Cape.

Constitution of the Republic of South Africa. (1996) Cape Town: Government of the Republic of South Africa.

Criminal Procedure Act (no. 51 of 1977) Cape Town: Government of the Republic of South Africa.

Du Plessis, A.A. (2010) 'Local environmental governance' and the role of local government in realising Section 24 of the South African Constitution. Stellenbosch Law Review, 21 (2), 265-97.

Economic Freedom Fighters $v$ Speaker of the National Assembly and Others; Democratic Alliance v Speaker of the National Assembly and Others [2016] ZACC 11 (verdict delivered by the Constitutional Court on 31 March 2016).

Fuo, O. (2014) Local government's role in the pursuit of the transformative constitutional mandate of social justice in South Africa. LLD Thesis, North West University, South Africa.

Fuo, O. (2015) Role of courts in interpreting local government's environmental powers in South Africa. Commonwealth Journal of Local Governance, 18, 17-35, http://dx.doi.org/10.5130/cjlg.v0i18.4840.

Godden, L. and Peel, J. (2010) Environmental law: Scientific, policy and regulatory dimensions. Melbourne: Oxford University Press.

Government of the Republic of South Africa and Others $v$ Grootboom and Others. (2000) (11) BCLR 1169 (CC) (verdict delivered by the Constitutional Court on 4 October 2000).

Humby, T. (2014) Localising environmental governance: The Le Sueur Case. PER/PELJ, 17 (4), 1659-1689. http://dx.doi.org/10.4314/pelj.v17i4.13

Khosa and Others $v$ Minister of Social Development and Others, Mahlaule and Another v Minister of Social Development. (2004) (6) BCLR 569 (CC) (verdict delivered by the Constitutional Court on 4 March 2004).

Lagoon Bay Lifestyle Estate (Pty) Ltd v Minister of Local Government, Environmental Affairs and Development Planning of the Western Cape and Others. (2011) (4) All SA 270 (WCC) (verdict delivered by the Western Cape High Court on 31 August 2011).

Le Sueur and Another v eThekwini Municipality and Others. [2013] ZAKZPHC 6 (30 January 2013) (verdict delivered by the Pietermaritzburg High Court on 30 January 2013). 
Maccsand (Pty) Ltd v City of Cape Town and Others. (2012) (4) SA 181 (CC) (verdict delivered by the Constitutional Court on 12 April 2012).

Marine Living Resources Act (no. 19 of 1998) Cape Town: Government of the Republic of South Africa.

Marius Nel and Others v Hessequa Local Municipality and Others (2015) (High Court, Western Cape Division, Cape Town) Case No 12576/2013, (verdict delivered by the Western Cape High Court on 14 December 2015.

National Environmental Management Act (NEMA) (no. 107 of 1998) Cape Town: Government of the Republic of South Africa.

National Water Act (NWA) (no. 36 of 1998) Cape Town: Government of the Republic of South Africa.

Olivier, N. (2015) Cooperative government and the intergovernmental division of environmental powers and functions. In Du Plessis, A.A. (ed.) Environmental law and local government in South Africa, pp. 345375. Cape Town: Juta.

Sv Makwanyane and Another. (1995) (6) BCLR 665 (CC) (verdict delivered by the Constitutional Court on 6 June 1995).

Snijman, P. and Petterson, T. (2015) Environmental law compliance and enforcement. In: Du Plessis, A.A. (ed.) Environmental law and local government in South Africa, pp. 291-318. Cape Town: Juta.

Steytler, N. and De Visser, J. (2014) Local government law of South Africa. Durban: LexisNexis. 